\title{
Association between integrin-linked kinase and hyperthermia in oral squamous cell carcinoma
}

\author{
JUN ZHAO ${ }^{1,2^{*}}$, NA LIU $^{2,3^{*}}$, XINHE HAO ${ }^{1}$, LIN QUE $^{2}$, JIYUAN LIU $^{2,4}$ and XIUFA TANG ${ }^{2,4}$ \\ ${ }^{1}$ Department of Oral and Maxillofacial Surgery, Hefei Stomatological Hospital, Hefei, Anhui 230001; ${ }^{2}$ State Key Laboratory \\ of Oral Diseases, West China College of Stomatology, Sichuan University, Chengdu, Sichuan 610041; ${ }^{3}$ Department of \\ Stomatology, The First Affiliated Hospital of Anhui Medical University, Hefei, Anhui 230001; ${ }^{4}$ Department of Head and \\ Neck Carcinoma, West China College of Stomatology, Sichuan University, Chengdu, Sichuan 610041, P.R. China
}

Received December 22, 2015; Accepted June 2, 2017

DOI: $10.3892 / \mathrm{ol} .2017 .7222$

\begin{abstract}
The present study aimed to observe the effect of the biological functions of integrin-linked kinase (ILK) silencing combined with hyperthermia on Tca8113 cells. Lentivirus-mediated short hairpin RNA (shRNA)-targeting ILK was transfected into oral squamous cell carcinoma (OSCC) Tca8113 cells and, combined with hyperthermia, several experimental methods were used to detect their biological behavior in vitro. On the basis of in vitro experiments, Tca8113 cells were transplanted into nude mice models, and ILK-shRNA-lentivirus was injected into the nude mice transplanted tumor and combined with hyperthermia. Tumor morphology and the associated protein expression changes were determined. Subsequent to ILK silencing combined with hyperthermia, the growth, migration and proliferation of Tca8113 cells were significantly inhibited. Flow cytometry revealed that the cells were blocked in the $S$ phase, and western blot analysis demonstrated that ILK, phosphorylated (p)-RAC-alpha serine/threonine-protein kinase (Akt), p-glycogen synthase kinase- $3 \beta$ and $p$-heat shock factor 1 protein expression levels were significantly decreased, while apoptosis-associated protein B-cell lymphoma-2-associated $\mathrm{X}$ protein expression and the efficacy of hypothermia were significantly increased. By ILK silencing combined with hyperthermia, a significant therapeutic effect on transplanted tumors was observed in nude mice. Immunohistochemistry revealed the same results as the in vitro experiments. ILK
\end{abstract}

Correspondence to: Dr Xiufa Tang, Department of Head and Neck Carcinoma, West China College of Stomatology, Sichuan University, Section 3, 14 Renmin South Road, Chengdu, Sichuan 610041, P.R. China

E-mail: 81561632@qq.com

*Contributed equally

Key words: oral squamous cell carcinoma, integrin-linked kinase, phosphatidylinositol-3-kinase/protein kinase B signaling pathway, RNA interference, hyperthermia, phospho-heat shock factor 1 silencing combined with hyperthermia can inhibit the growth, proliferation and migration of Tca8113 cells, promote Tca8113 cell apoptosis, inhibit the phosphatidylinositol-3-kinase/Akt signaling pathway and increase hyperthermia sensitivity; the combination therapy exhibits a synergistic sensitizing effect. Therefore, ILK silencing combined with hypothermia may serve as a novel combination therapy strategy against OSCC.

\section{Introduction}

Oral squamous cell carcinoma (OSCC) is a type of malignant tumor with a high degree of malignancy and invasion. Following a single surgery, there are clear defects and severe deformities in the maxillofacial of patients, and tumor relapse is likely to occur. The effect of a single radiotherapy or chemotherapy is not satisfactory, and there are many side effects. The study of OSCC has focused on integrated sequential therapy, although there has been difficulty in this research area, for example, the cure rate is not high, the prognosis is poor and the postoperative survival quality is not high. Thus, there is an urgent requirement to explore and seek the best combination in order to obtain the best treatment effect (1).

Phosphatidylinositol-3-kinase (PI3K) signaling is involved in numerous cellular functions, including cell proliferation, differentiation, apoptosis and glucose transportation (2). It was revealed that signaling of $\mathrm{PI} 3 \mathrm{~K}$ and its downstream molecule protein kinase $\mathrm{B} / \mathrm{RAC}$-alpha serine/threonine-protein kinase (PKB or Akt) are associated with human tumor occurrence and development (3). Integrin-linked kinase (ILK) is a Serine/Threonine protein kinase, which can be activated in a PI3K-dependent manner by a growth factor or integrin (4). ILK is activated through phosphorylation of the downstream substrates of PKB/Akt and inhibition of glycogen synthase kinase (GSK) 3, so that the extracellular signals are passed downstream, and regulate cell growth, differentiation and migration $(5,6)$. In a number of tumors, ILK is overexpressed, and overexpression or constitutive activation of ILK is associated with tumor formation, invasion and metastasis. Inhibition of ILK activity can lead to cell cycle arrest and apoptosis $(7,8)$, making it an ideal target for gene therapy of tumors. However, for single-gene therapy there are deficiencies and side effects (it cannot cure the disease and may trigger new genetic 
mutations), and it is difficult to achieve the best treatment effect (4).

Hyperthermia is an important means of adjuvant therapy. Compared with surgery, radiotherapy and chemotherapy, hyperthermia has minimally invasive or even non-invasive and non-toxic side effects, and it can effectively kill tumor cells and improve the quality of life of patients (9-11). However, in the process of hyperthermia, it was revealed that when the repetitions of hyperthermia are increased, the effect of hyperthermia is reduced, and a thermal tolerance phenomenon has been reported $(9,10)$. Due to the existence of thermal tolerance mechanisms, the clinical application of hyperthermia is limited. Therefore, it is important to improve the efficiency of clinical hyperthermia and to remove the thermal tolerance of tumor tissues in order to improve sensitivity to hyperthermia.

Heat shock protein (HSP) expression is mediated by heat shock factor 1 (HSF1) (12). Previous studies have demonstrated that PI3K can influence HSF1 activity, thus affecting the expression of HSP (10). One such study demonstrated that inhibition of the PI3K/Akt signaling pathway can reduce the expression of HSP70 (13). Another previous study has demonstrated that activation of Akt [phosphorylated-Akt; (p)-Akt] can promote the phosphorylation of GSK $3 \beta$ and lead to inactivation of GSK3 $\beta$ (6). Inactivation of GSK3 $\beta$ leads to HSF1 activation (14), which may be the reason that PI3K inhibits the expression of HSP70 induced by hyperthermia.

In a previous study from our group (15), an ILK-siRNA lentiviral expression vector was successfully constructed and transfected into tongue squamous cell carcinoma Tca8113 cells. Subsequent to silencing ILK, Tca8113 cell growth, proliferation and migration were inhibited, and apoptosis increased. Following hyperthermia, similar changes were observed in Tca8113 cells. Therefore, the present study aimed to investigate whether a combination of ILK silencing and hyperthermia can induce a synergistic sensitizing effect and exhibit an improved antitumor effect.

By way of gene therapy, the impact of the biological functions of ILK gene silencing combined with hyperthermia on Tca8113 cells was observed, and it was investigated whether combination therapy is the synergistic sensitizing effect. The relevant mechanisms were analyzed, and an objective basis was provided for gene silencing therapy and hyperthermia combined treatment of OSCC.

\section{Materials and methods}

Cell line and cell culture. Human tongue squamous cell carcinoma Tca8113 cells were obtained from the State Key Laboratory of Oral Diseases, Sichuan University (Chengdu, China) and cultured in Dulbecco's modified Eagle's medium (Gibco; Thermo Fisher Scientific, Inc., Waltham, MA, USA) supplemented with $10 \%$ fetal bovine serum (FBS; Hyclone; GE Healthcare Life Sciences, Logan, UT, USA) and 1\% penicillin/streptomycin at $37^{\circ} \mathrm{C}$ in a humidified atmosphere with $5 \% \mathrm{CO}_{2}$. Cells were routinely passaged every $2-3$ days by trypsinization (Gibco; Thermo Fisher Scientific, Inc.). Cells at the logarithmic growth phase were used in the present study.

Hyperthermia of Tca8113 cells. With reference to the literature (16), eight time points for heating the cells were selected as follows: NT (no heating), $0 \mathrm{~h}$ (cells were subjected to heat shock at $45^{\circ} \mathrm{C}$ for $30 \mathrm{~min}$, and then allowed to recover by incubation in a $37^{\circ} \mathrm{C}$ chamber for an additional $0,2,4,6,8,10$ and $24 \mathrm{~h}$ ).

Reverse transcription-quantitative polymerase chain reaction $(R T-q P C R)$ analysis. Each experiment was conducted in duplicate and repeated 3 times. RT-qPCR was performed using the SYBR Premix ExTaq reagent (Invitrogen; Thermo Fisher Scientific, Inc.). Total RNA was extracted from Tca8113 cells using QIAGEN RNeasy mini kit (cat. no. 74104; Qiagen $\mathrm{GmbH}$, Hilden, Germany) and isolated using TRIzol reagent (Invitrogen; Thermo Fisher Scientific, Inc.). The total RNA was reverse transcribed into cDNA using a PrimeScript RT reagent kit with gDNA Eraser (cat. no. DRR037A; Perfect Real Time; Takara Biotechnology Co., Ltd., Dalian, China) according to the manufacturer's protocol. The reverse transcription reaction conditions were as follows: $95^{\circ} \mathrm{C}$ for $5 \mathrm{~min}$, followed by 35 cycles of $94^{\circ} \mathrm{C}$ for $45 \mathrm{sec}, 55^{\circ} \mathrm{C}$ for $45 \mathrm{sec}$ and $75^{\circ} \mathrm{C}$ for 15 sec. The resulting cDNA was quantified by a RT-qPCR mRNA SYBR-Green detection kit (Takara Biotechnology Co., Ltd.) according to the manufacturer's protocol. Each reaction was performed in a total volume of $20 \mu \mathrm{l}(10 \mu \mathrm{l}$ Premix, $0.8 \mu \mathrm{l}$

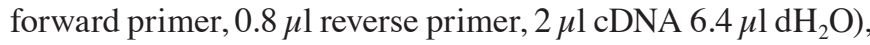
using SYBR-Green PCR reagents (Takara Biotechnology Co., Ltd.). The following primers were used: ILK forward, 5'-TTTGCAGTGCTTCTGTGGGAA-3' and reverse, 5'-CTA CTTGTCCTGCATCTTCTC-3'; HSF1 forward, 5'-CCAGCA ACAGAAAGTCGTCAAC-3' and reverse, 5'-GGCTATACT TGGGCATGGAATG-3'; and human-actin forward, 5'-CCA CGAAACTACCTTCAACTCC-3' and reverse, 5'-GTGATC TCCTTCTGCATCCTGT-3'. qPCR was performed using QuantStudio $^{\text {TM }} 3$ and 5 Real-Time PCR systems (Thermo Fisher Scientific, Inc.) The reaction conditions were as follows: $95^{\circ} \mathrm{C}$ for $30 \mathrm{sec}$, followed by 40 cycles of $95^{\circ} \mathrm{C}$ for $5 \mathrm{sec}$ and $60^{\circ} \mathrm{C}$ for $31 \mathrm{sec}$. The relative expression levels of mRNA in each sample were calculated using the $2^{-\Delta \Delta \mathrm{Cq}}$ method (14). The products were analyzed on $1 \%$ agarose gels and observed under ultraviolet light (Bio-Rad Laboratories, Inc., Hercules, CA, USA).

Western blot analysis. Whole cell extracts were harvested in radio immuno-precipitation assay buffer $(150 \mathrm{mM} \mathrm{NaCl}, 50 \mathrm{nM}$ Tris $\mathrm{pH} 8.0,0.5 \%$ sodium deoxycholate, $0.1 \%$ Triton $\mathrm{X}-100$, $0.1 \%$ SDS, 2 mM EDTA and 5\% glycerol) and homogenized for $5 \mathrm{~min}$ at $447 \mathrm{x} \mathrm{g}$ and harvested at room temperature. Total protein concentrations were determined using a BCA assay (Nanjing Kaiji Biotechnology Development Co. Ltd., Jiangsu, China). Total proteins were loaded per lane and separated on an SDS-PAGE gel by electrophoresis, and transferred to a nitrocellulose membrane (the mass of protein loaded per lane was $40 \mu \mathrm{g}$, the percentage of the concentrate gel was $4 \%$, the percentage of the isolate gel was $10 \%$ ). The nitrocellulose membrane was blocked with 5\% skim milk in TBST (137 mM Cl, $20 \mathrm{mM}$ Tris- $\mathrm{HCl} \mathrm{pH}$ 7.6, 0.1\% Tween-20), and incubated at $37^{\circ} \mathrm{C}$ for $1 \mathrm{~h}$. Membranes were probed with the indicated primary antibodies, against anti-ILK (cat. no. 3862; 1:100; Cell Signaling Technology, Inc., Danvers, MA, USA), anti-p-Akt (cat. no. 9271; 1:300; Cell Signaling Technology, Inc.), AKT (Ser-473) (cat. no. 9272; 1:300; Cell Signaling Technology, Inc.), 
p-GSK3 3 (Ser-9) (cat. no. BS6365; 1:100; BioWorld Technology, Inc., St. Louis Park, MN, USA), GSK3 $\beta$ (cat. no. BS4084; 1:100; BioWorld Technology, Inc.), anti-p-HSF1 (Ser-303/307) (cat. no. 2108-1; 1:100; Epitomics; Abcam, Cambridge, UK), anti-HSF-1 (cat. no. 2043-1; 1:100; Epitomics; Abcam), anti-B cell-2-associated X protein (Bax; cat. no. BS6420;1:100; BioWorld Technology, Inc.) and anti-GAPDH (cat. no. 5174; 1:1,000; Cell Signaling Technology, Inc.) at $4^{\circ} \mathrm{C}$ overnight. The following day, membranes were incubated with the Horseradish Peroxidase Rabbit anti-Horseradish Polyclonal Antibody (cat. no. LS-C74277, 1:5,000; LifeSpan Biosciences, Inc.) at room temperature for $1 \mathrm{~h}$. Proteins were detected using ECL luminous fluid (cat. no. WBKLS0050; EMD Millipore, Billerica, MA, USA), and autographed onto an X-ray film.

Transduction and hyperthermia. Tca8113 cells were grown at a density of $5 \times 10^{4} /$ well in a 12 -well plate in RPMI-1640 medium until they reached $30-50 \%$ confluency and incubated with $5 \% \mathrm{CO}_{2}$ in air. ILK-shRNA-lentivirus was introduced for $12 \mathrm{~h}$ when the multiplicity of infection was 50. After 5 days, cells were heated at $45^{\circ} \mathrm{C}$ for $30 \mathrm{~min}$. Subsequent to heating for $8 \mathrm{~h}$ at $37^{\circ} \mathrm{C}$ in the $\mathrm{CO}_{2}$ incubator; cells were centrifuged for $5 \mathrm{~min}$ at $447 \mathrm{x} \mathrm{g}$ at room temperature, the upper cleaning fluid was removed and cells were harvested at room temperature.

MTT assay. Cells were seeded at a density of $1 \times 10^{3} /$ well on 96-well plates and incubated at $37^{\circ} \mathrm{C}$ overnight, and further incubated with $0.5 \mathrm{mg} / \mathrm{ml}$ MTT (Sigma-Aldrich; Merck KGaA). After $4 \mathrm{~h}$ of incubation, the medium was replaced with $150 \mathrm{ml}$ DMSO (Sigma-Aldrich; Merck KGaA) and heated for $10 \mathrm{~min}$. Absorbance was then measured at a wavelength of $490 \mathrm{~nm}$ using a multiwell spectrophotometer (Bio-Rad Laboratories, Inc.). Cell inhibition rate (\%) was calculated as follows: The inhibition rate $=($ control group - experiment group $) /$ control group $\mathrm{x} 100 \%$. The experiment was repeated three times.

Colony formation assay. Tumor cells were plated at a density of $100 /$ well on 6 -well plates and cultured at $37^{\circ} \mathrm{C}$. Following culture for 3 weeks, colonies were stained with crystal violet $(0.005 \%)$ for $20 \mathrm{~min}$ at $37^{\circ} \mathrm{C}$ and images were captured by optical microscopy (Olympus Corporation, Tokyo, Japan). The colony formation rate was then calculated as follows: The colony formation rate $=$ number of colonies/number of inoculated cells x100.

Cell cycle analysis. Flow cytometry was used to analyze the cell cycle. Initially, cells were cultured in serum-free RPMI-1640 medium for $24 \mathrm{~h}$ at $37^{\circ} \mathrm{C}$ to induce cell cycle synchronization. Floating and attached cells were collected and centrifuged for $5 \mathrm{~min}$ at $447 \mathrm{x} \mathrm{g}$ at room temperature prior to washing with cold PBS. Cells were then fixed in $70 \%$ cold ethanol overnight at $4^{\circ} \mathrm{C}$. RNase A (100 $\mu \mathrm{l}$; Sigma Aldrich; Merck KGaA) and a fluorochrome solution containing $400 \mu \mathrm{l}$ propidium iodide (BestBio, Shanghai, China) and 1\% Triton X-100 were added and cells were incubated in the dark at room temperature for $30 \mathrm{~min}$. Cell cycle analysis was performed using a Coulter Epics XL/XL-MCL flow cytometer (Beckman Coulter, Inc., Brea, CA, USA) and analyzed using Quantity One software (version 3.0; Bio-Rad Laboratories, Inc.). All experiments were performed three times.
Ethics statement. Animal care and use were conducted in accordance with the Animal Research Institute Committee guidelines of Sichuan University (Chengdu, China). Mice were housed in a temperature-controlled room at $37^{\circ} \mathrm{C}$ with appropriate dark-light cycles $(10 \mathrm{~h}$ of light and $14 \mathrm{~h}$ of darkness), fed with a regular diet and maintained under the care of the Laboratory Animal Unit, Sichuan University. The mice were sacrificed by cervical dislocation. The present study was approved by the Committee of Animal Research, Institute of Sichuan University (Sichuan, China).

Xenograft tumor model and treatments. Tca8113 cells $\left(2 \times 10^{6}\right)$ in $100 \mu \mathrm{l}$ medium were harvested for $5 \mathrm{~min}$ at $447 \mathrm{x} \mathrm{g}$ at room temperature and injected subcutaneously into the hind dorsalis pedis of $60 \mathrm{SPF} \mathrm{BALB/cnu/nu} \mathrm{female} \mathrm{mice} \mathrm{(Charles}$ River Japan, Japan) at the Laboratory Animal Unit, Sichuan University (6 weeks old; weight, 18-22 g). After 1 week, $10^{8}$ TU ILK-shRNA-lentivirus and NC-shRNA-lentivirus (NC) were injected into tumors, respectively, suspended in $50 \mu 1$ RPMI-1640 medium (Gibco; Thermo Fisher Scientific, Inc.) containing $10 \% \mathrm{FBS}$ and $5 \mathrm{mg} / \mathrm{ml}$ polybrene (Shanghai GeneChem Co., Ltd., Shanghai, China). Mice were heated in a water bath at $45^{\circ} \mathrm{C}$ for $30 \mathrm{~min}$ and were administered a second hyperthermic dose after 1 week.

Tumor size and weight measurement. Each tumor was measured weekly with a caliper every 3 days, and the following formula was used to calculate tumor volumes $=1 / 2 \mathrm{xAxB}^{2}$, where $\mathrm{A}$ and $\mathrm{B}$ represent the larger and smaller tumor diameters, respectively (15). Mice were sacrificed at 28 days after first hyperthermia. The tumor tissue was removed, weighed and the heart, liver, brain, spleen, lung and kidney of mice were removed, fixed with $4 \%$ paraformaldehyde for $24 \mathrm{~h}$ at room temperature and embedded.

Hematoxylin and eosin (H\&E) staining. Paraffin-embedded mouse extracted organs sections, including the heart, liver, brain, spleen, lung or kidney (sectioned at $4 \mu \mathrm{m}$ ) were prepared by a routine procedure (16).

Immunohistochemistry. Immunohistochemical staining was performed using the streptavidin-biotin-peroxidase complex method. The primary antibodies used were: ILK (cat. no. 3862; 1:100; Cell Signaling Technology, Inc.), p-Akt (cat. no. 9271; 1:300; Cell Signaling Technology, Inc.), total Akt (cat. no. 9272; 1:300; Cell Signaling Technology, Inc.), p-GSK3 $\beta$ (cat. no. BS6365; 1:100; BioWorld Technology, Inc.), total GSK3 $\beta$ (cat. no. BS4084; 1:100; BioWorld Technology, Inc.), Bax (cat. no. bs2538; 1:100, BioWorld Technology, Inc.), p-HSF1 (cat. no. pS303/307; 2108-1, 1:100; Epitomics; Abcam) and total HSF1 (2043-1; 1:100, Epitomics; Abcam). Normal rabbit IgG (cat. no. 2729S; Cell Signaling Technology, Inc.) was substituted for each primary antibody as a negative control. All sections were incubated for $1 \mathrm{~h}$ at room temperature, and then were incubated overnight at $4^{\circ} \mathrm{C}$. After being washed with phosphate-buffered saline (PBS), sections were incubated with $100 \mu \mathrm{l}$ biotinylated goat anti-rabbit IgG (cat. no. PAB9401; Abnova; Taipei City, Taiwan) for $30 \mathrm{~min}$ at room temperature. They were then washed three times with PBS, treated with streptavidineperoxidase reagent for $30 \mathrm{~min}$, and 
rewashed with PBS three times. The reactions were visualised with DAB kits (cat. no. ST033; Guangzhou Whiga Technology Co., Ltd., Guangzhou, China) as chromogen, and sections were counterstained with haematoxylin. (Sigma-Aldrich; Merck $\mathrm{KGaA}$ ) for $2 \mathrm{~min}$ at room temperature, until the nucleus to blue.

A total of four high-power fields were analyzed at x400 magnification with a light microscope (Olympus Corporation, Toyko, Japan) from a single representative tissue section $(4 \mathrm{ct})$. Fields of interest were selected to reflect the area of highest intensity staining and highest percentage of cells that were positive, and scored and the mean was recorded. The percentage of positive cells was assessed by counting manually. Each sample field was assigned a value between 0 and 4 ( 0 , negative; $1,15 \%$ of the cells with positive staining; $2,5-50 \%$ of the cells with positive staining; $3,>50 \%$ of the cells with weak staining and $4,>50 \%$ of the cells with strong staining) for ILK, p-Akt, p-GSK3 $\beta$ and Bax (14). The proportion of p-HSF1-positive cells was determined by counting 100 cells in six random fields from each section.

Terminal deocynucleotidyl-transferase-mediated dUTP nick end labeling (TUNEL) analysis. Tissue sections of the tumors were fixed in $10 \%$ neutral buffered formalin (Thermo Fisher Scientific, Inc.) for $24 \mathrm{~h}$ at $4^{\circ} \mathrm{C}$ and were prepared in a routine manner, washed in $0.01 \mathrm{M}$ PBS and incubated with 501 TUNEL reaction mixture (prepared by mixing a terminal deoxynucleotidyl transferase enzyme solution with a solution containing a fluorescence-producing agent in a 1:1 ratio) at $37^{\circ} \mathrm{C}$ for $60 \mathrm{~min}$. The negative control sections were treated with PBS to replace terminal deoxynucleotidyl transferase using the rubber sealing process. In total, five high-power fields at x400 magnification were analyzed through a fluorescence microscope (Leica Microsystems, Inc., Buffalo Grove, IL, USA) from a single representative tissue section, selected to reflect the area of highest intensity staining and highest percentage of cells nuclei that were stained red, were scored.

Statistical analysis. Measurement data are expressed as the mean \pm standard deviation. All experimental and control groups were compared using one-way analysis of variance. Multiple comparisons between the groups were performed using Student-Neuman-Keuls test. All statistical tests were performed using SPSS statistical software, version 13.0 (SPSS, Inc., Chicago, IL, USA). P-values were two-tailed. $\mathrm{P}<0.05$ was considered to indicate a statistically significant difference.

\section{Results}

shRNA transfection effectively decreases the expression of $I L K$ in OSCC cells. To observe the function of ILK in OSCC, ILK expression was knocked down in the OSCC cell line. Specific ILK downregulation was confirmed by reduced expression of ILK mRNA and protein in cells transfected with shRNAs. A large number of cells illuminated bright green, which represented the high transfection efficiency. Green fluorescence was not detected in non-transfected cells. The transduction efficiency was $90 \%$ (Fig. 1A and B) and the silencing efficiency was $75 \%$, calculated by the mean of qPCR and western blot analysis (Fig. 1C and D).
Detection of the optimal time for gene silencing. In order to obtain the optimal time point of thermal tolerance, the expression of thermal-associated factors was measured. If silencing ILK sensitized hyperthermia at a specific time point, then silencing ILK should sensitize hyperthermia more in other low thermal tolerance conditions. By qPCR analysis, it was revealed that the expression of ILK mRNA was highest $6 \mathrm{~h}$ after hyperthermia (Fig. 1E), and HSF1 expression peaked 2 and $6 \mathrm{~h}$ after hyperthermia (Fig. 1F). Western blot analysis revealed that the expression of p-HSF1 protein peaked $8 \mathrm{~h}$ after hyperthermia, and the expression of Bax protein was highest $6 \mathrm{~h}$ after hyperthermia $(\mathrm{P}<0.01$; Fig. $1 \mathrm{G}$ and $\mathrm{H})$. Finally, $8 \mathrm{~h}$ post-hyperthermia was found to be the optimal time for gene silencing.

ILK silencing combined with hyperthermia inhibits cell proliferation, migration and cell cycle in vitro. The contribution of ILK silencing combined with hyperthermia to OSCC cell proliferation was explored. MTT assays were employed in the present study. The results demonstrated that the (KD + HT group; ILK silencing combined with hyperthermia group) grew significantly more slowly compared with other groups $(\mathrm{P}<0.01)$. No significant difference was detected in cells treated with NC-shRNA-lentivirus compared with untreated cells (Fig. 2A).

The present study sought to determine the contribution of ILK silencing combined with hyperthermia to OSCC cell migration. Colony forming assays were employed in the present study; the colony formation rate of untreated cells was $0.185 \pm 0.007$, while that of the NC group was $0.174 \pm 0.011$. The colony formation rate of the KD + HT group $(0.004 \pm 0.000)$ was significantly lower compared with the KD group $(0.015 \pm 0.001)$, and the colony formation rates of two groups were significantly lower compared with the other groups $(\mathrm{P}<0.01$; Fig. $2 \mathrm{~B}$ and $\mathrm{C})$.

Flow cytometry was used to assess changes in the cell cycle. Cell retention in the $\mathrm{S}$ phase of the KD and KD + HT groups was significantly increased compared with the other groups $(\mathrm{P}<0.01)$, and that of the KD + HT group was increased compared with the KD group (Fig. 3). This indicated that the cells were blocked in G2 phase, and could not undergo mitosis, resulting in apoptosis.

ILK silencing combined with hyperthermia promotes apoptosis. The expression of Bax could regulate cell apoptosis. Western blot analysis was employed to measure the change of the associated protein in the present study. It was found that the expression of $\mathrm{p}$-Akt and p-GSK3 $\beta$ were reduced, resulting in downregulation of p-HSF1 expression, and eventually leading to upregulation of the apoptosis-associated protein Bax. The variation tendency of protein expression in the KD + HT group was comparable to that in the KD group, however the effect was more significant $(\mathrm{P}<0.01$; Fig. $4 \mathrm{~A}$ and $\mathrm{B})$.

In vivo analysis: ILK silencing combined with hyperthermia inhibits tumor growth. Following inoculation for 7 days, the xenograft tumor formed. Mice were sacrificed at 28 days after the first hyperthermia. The tumor volume of the KD + HT group was the smallest, followed by that of the KD group; subsequent to treatment, it was revealed that the tumor volume and weight of the KD + HT group were the smallest in all groups $(\mathrm{P}<0.01$ vs. all other groups; Fig. $4 \mathrm{C}$ and $\mathrm{D})$. The tumor 
A

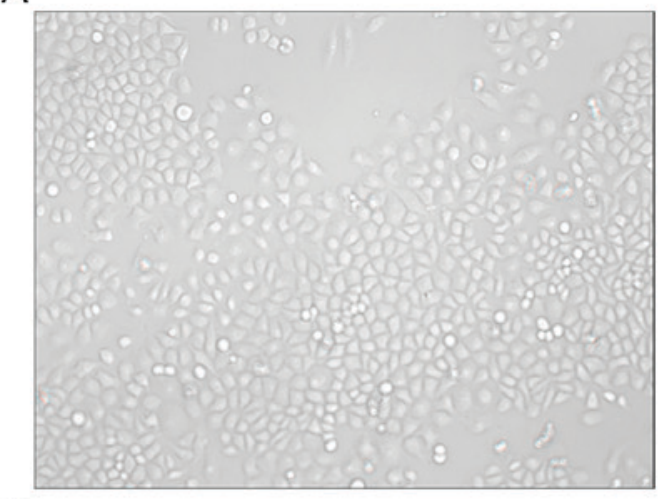

C

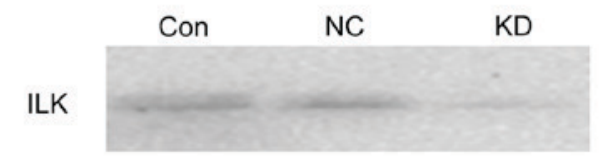

GAPDH

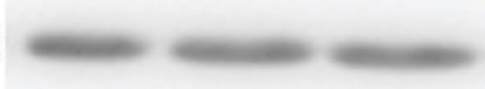

E

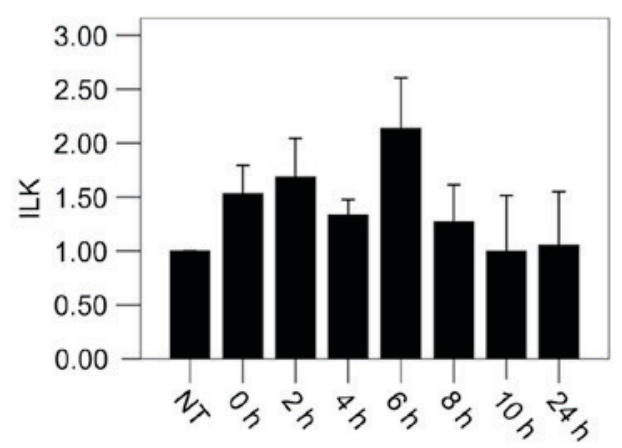

G

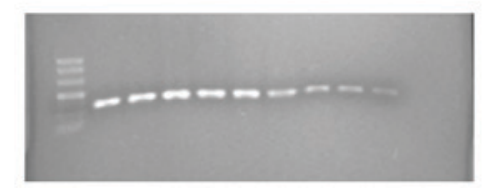

B

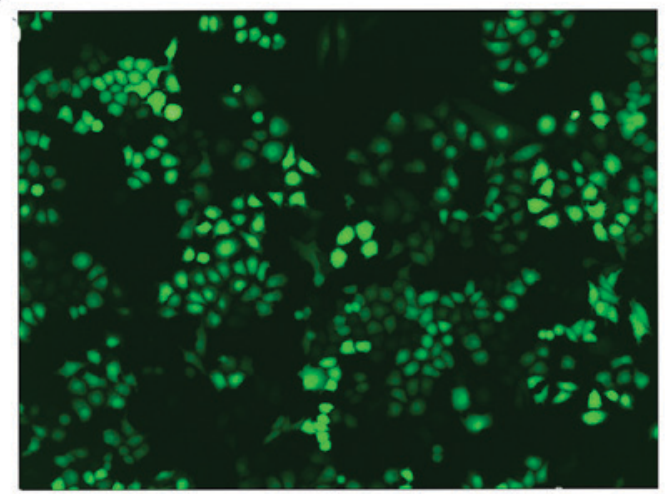

D

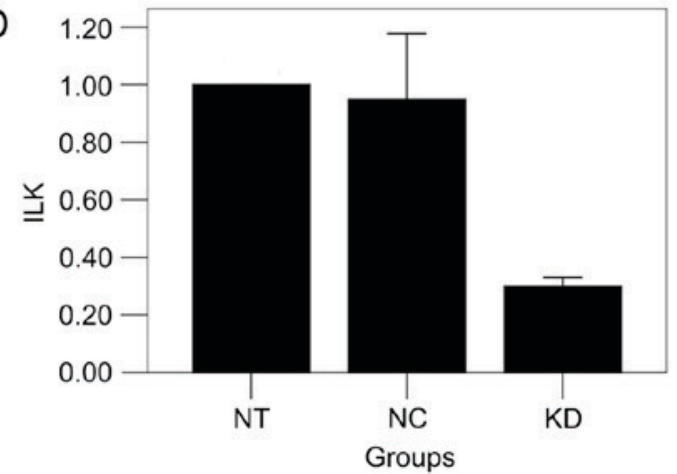

F

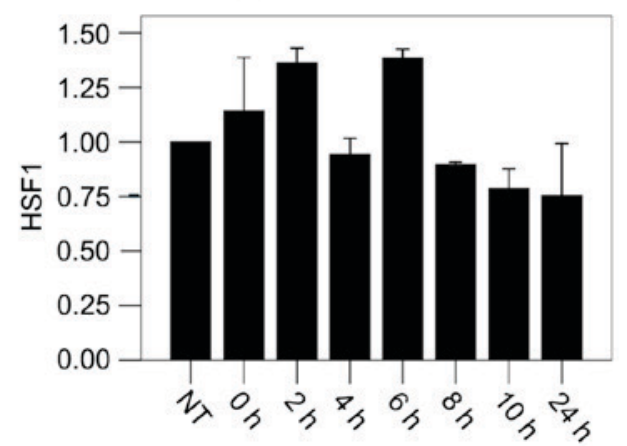

$\mathrm{H}$

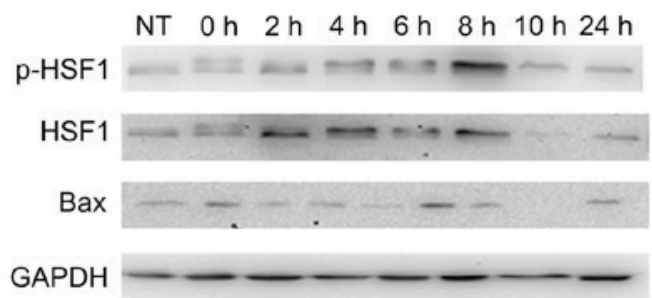

Figure 1. siRNA transfection effectively silenced ILK inoral squamous cell carcinoma cell lines. (A) Prior totransduction. (B) Five days after transduction. (C) siRNA effectively silenced ILK in protein levels. (D) siRNA effectively silenced ILK in mRNA levels. (E) ILK mRNA was detected following hyperthermia by qPCR. (F) HSF1 mRNA was detected following hyperthermia by qPCR. (G) Results of agarose gel electrophoresis. (H) Expression of p-HSF1 and Bax in protein levels was detected by western blot analysis following hyperthermia $(\mathrm{P}<0.01)$. qPCR, quantitative polymerase chain reaction; siRNA, small interfering RNA; ILK, integrin-linked kinase; HSF1, heat shock factor 1; p-, phosphorylated.

surface of the two groups were yellow-green, the membrane was intact, and adhesion and infiltration were not observed compared with all other groups (Fig. 5A).

\section{In vivo analysis}

Microscope observation of xenograft tumor. No significant organic damage was observed in the heart, liver, brain, spleen, lung or kidney by H\&E staining (Fig. 5B). Subsequent to H\&E staining, polygonal cells were in dense flocks and nuclei were large and deeply stained in the control and the NC group; tumor cells were distributed sparsely, some cells shrunk and became round and nuclei were pyknotic and darkly stained in the HT group and the NC + HT group; tumor cells were small and distribution was sparse, most cells shrunk and became round and nuclei were pyknotic and darkly stained in the KD group and the KD + HT group (Fig. 5C-H). 
A

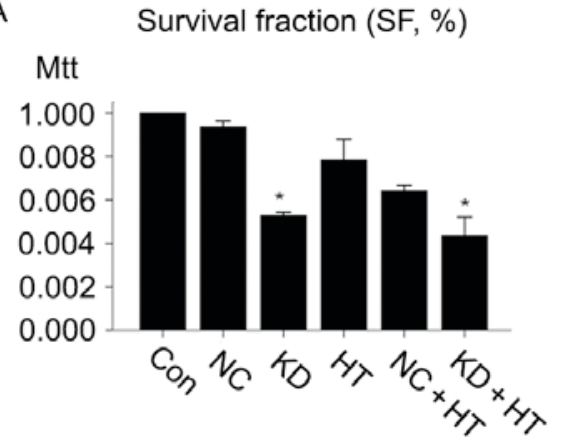

B Colony forming efficiency (SF,\%)

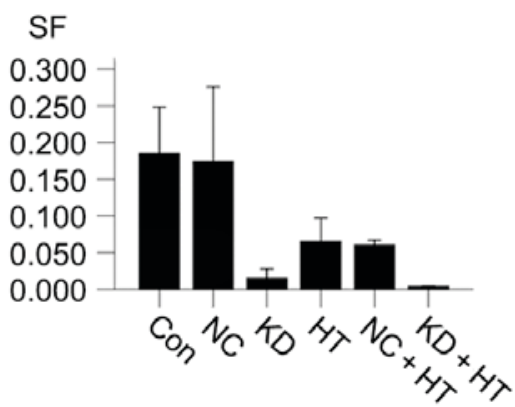

C

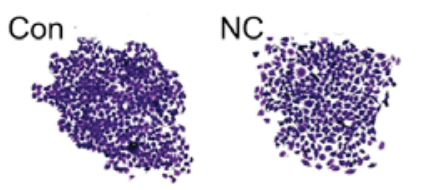

KD
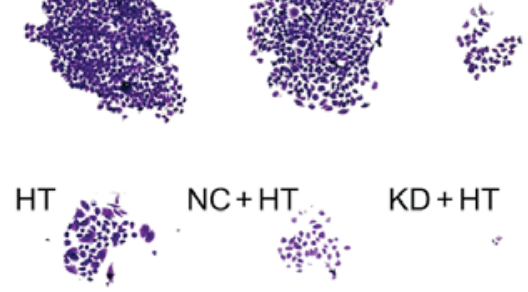

Figure 2. (A) Effect of ILK silencing combined with hyperthermia on the cell growth of OSCC cells by MTT assays. The cells grew significantly more slowly $(\mathrm{P}<0.01)$. (B) Effect of ILK silencing combined with hyperthermia on cell migration of OSCC cells by colony forming assay $(\mathrm{P}<0.01)$. The colony formation rate was significantly decreased. (C) The colony formation of each group. ${ }^{*} \mathrm{P}<0.01$, the cells which in KD+HT group and in KD group grew significantly more slowly compared with other groups after ILK silencing. ILK, integrin-linked kinase; NC, negative control; Con, control; HT, hyperthermia; KD, ILK silencing; SF, surviving factor; OSCC, oral squamous cell carcinoma.

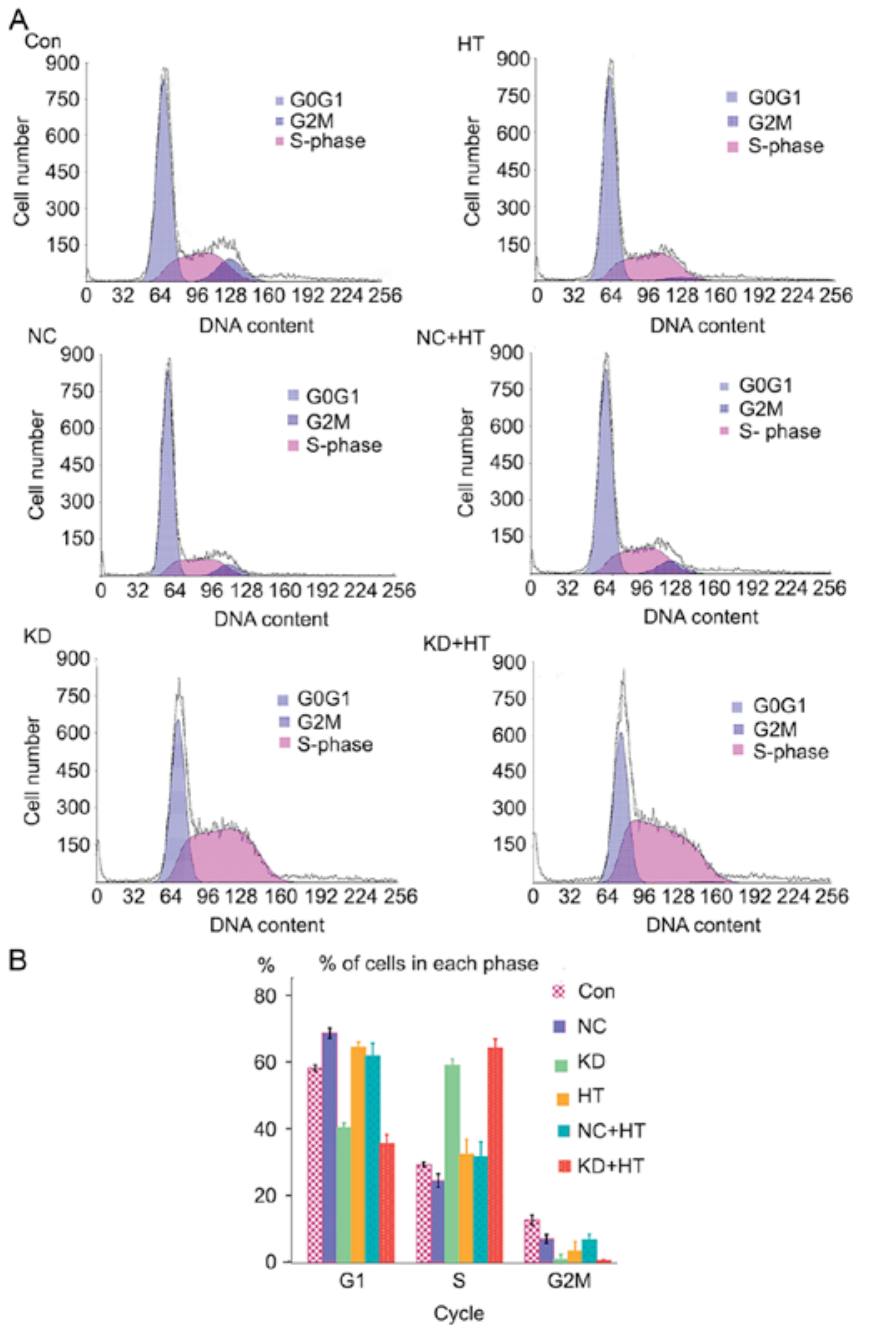

Figure 3. (A) Effect of ILK silencing combined with hyperthermia on cell cycle of oral squamous cell carcinoma cells by flow cytometry. (B) The cells were blocked in the $\mathrm{S}$ phase following ILK silencing combined with hyperthermia $(\mathrm{P}<0.01)$. ILK, integrin-linked kinase; NC, negative control; Con, control; KD, ILK silencing; HT, hyperthermia.

Immunohistochemical analysis detected positive ILK, p-Akt and p-GSK3 $\beta$ expression, predominantly in the cytoplasm and occasionally in the nucleus, while positive expression
Table I. Quantitative analysis of ILK, p-Akt, p-GSK3 $\beta$, p-HSF1 and Bax expression detected by immunohistochemical analysis.

\begin{tabular}{lccccc}
\hline Groups & ILK & p-Akt & p-GSK3 $\beta$ & Bax & p-HSF1 \\
\hline CON & 4 & 4 & 4 & 2 & $78.6730 \pm 3.86401$ \\
NC & 4 & 4 & 4 & 2 & $78.7240 \pm 2.77414$ \\
HT & 3 & 3 & 3 & 2 & $59.1380 \pm 1.96891$ \\
NC+HT & 3 & 3 & 3 & 2 & $59.1980 \pm 3.01508$ \\
KD & 2 & 2 & 2 & 3 & $29.4220 \pm 3.13326$ \\
KD+HT & 2 & 2 & 2 & 3 & $22.0400 \pm 2.11737$
\end{tabular}

ILK, integrin-linked kinase; p-GSK1 $\beta$, phosphorylated-glycogen synthase kinase $1 \beta$; Bax, B cell-2-associated X protein; CON, control; $\mathrm{NC}$, negative control; HT, hyperthermia; KD, ILK silencing.

of p-HSF1 was detected predominantly in the nucleus and occasionally in the cytoplasm. Positive Bax expression was detected mainly in the cytoplasm and occasionally in the membrane. The results of quantitative analysis are presented in Table I. Positive p-HSF1 expression in the KD + HT group was the least detectable $(\mathrm{P}<0.01$; Fig. $5 \mathrm{C}-\mathrm{H})$.

In TUNEL analysis, cell apoptosis was significantly increased in the KD group and the KD + HT group. The highest number of apoptotic cells was observed in the KD + HT group, fewer apoptotic cells were found in the HT group and the $\mathrm{NC}+\mathrm{HT}$ group, and the fewest number of apoptotic cells was observed in the control group and $\mathrm{NC}$ group $(\mathrm{P}<0.01$; Fig. $5 \mathrm{I})$.

\section{Discussion}

At present (17-23), it is recognized internationally that cancer progression is a multi-factorial, multi-step, multi-stage process, which involves a variety of changes in gene expression. Subsequent to being subjected to thermal stimulation, the cells produce a heat shock response, and their role in the resistance to heat and other stress response is enhanced (24). Cells express HSPs to fight heat stress, and the expression of HSPs is regulated by HSF1 (12). Therefore, the efficacy of hyperthermia can 
A

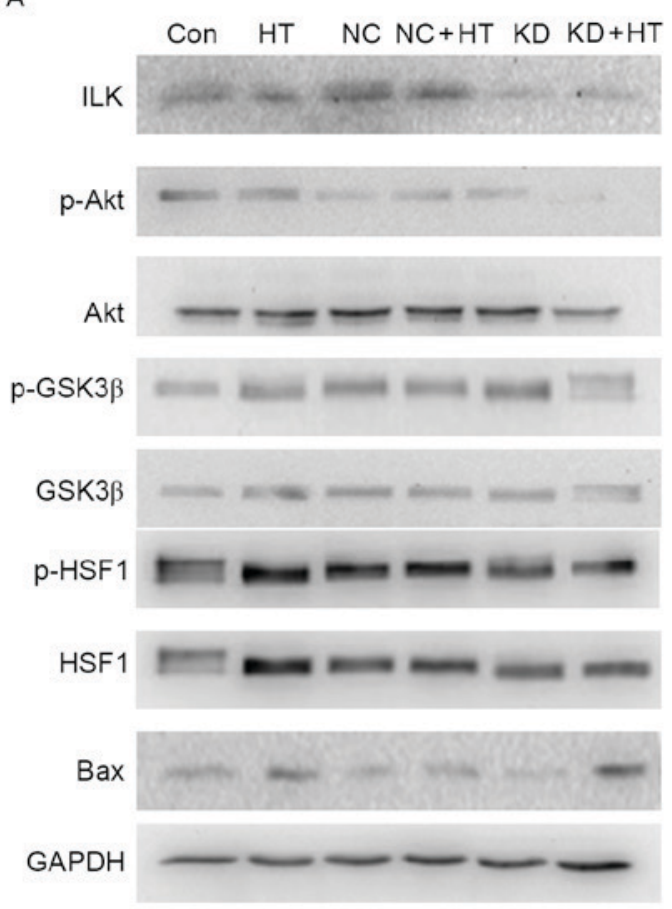

B

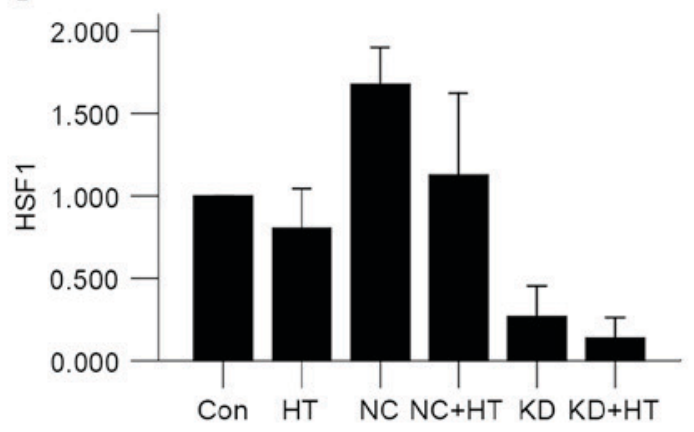

C

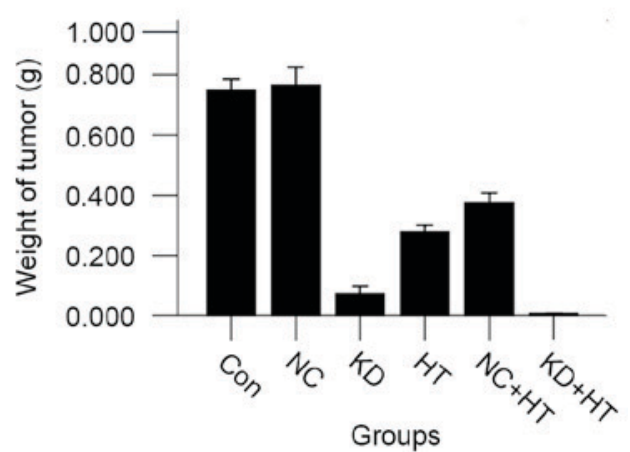

D
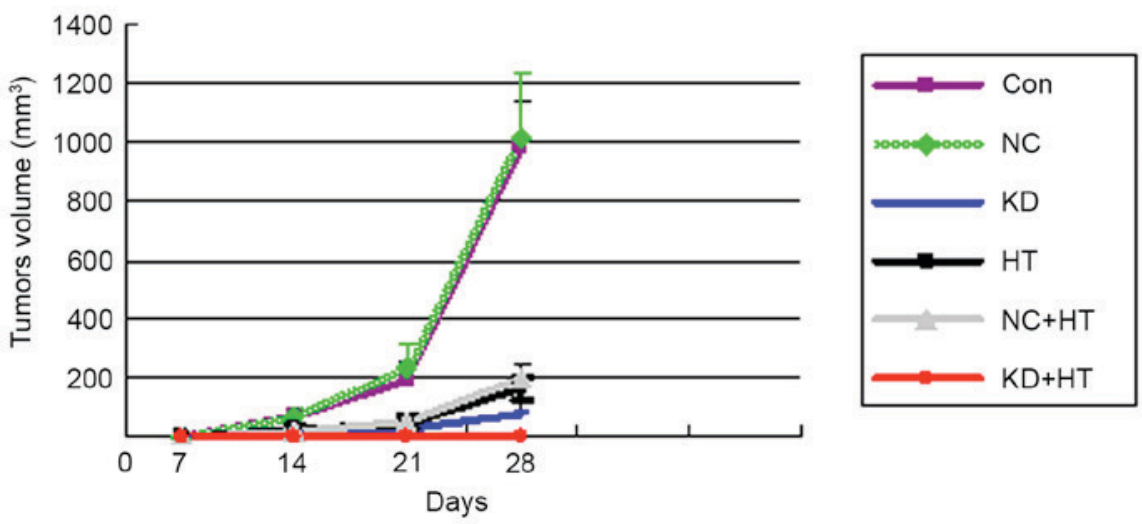

Figure 4. (A) By western blot analysis, ILK silencing combined with hyperthermia could inhibit the proteins level of p-Akt, p-GSK3 $\beta$ and p-HSF1, and promote the expression of Bax protein $(\mathrm{P}<0.01)$. (B) The $\mathrm{p}-\mathrm{HSF} 1$ expression was lowest in the KD + HT group. (C) ILK silencing combined with hyperthermia reduced tumor weight $(\mathrm{P}<0.01)$. (D) ILK silencing combined with hyperthermia reduced tumor volume $(\mathrm{P}<0.01)$. ILK, integrin-linked kinase; $\mathrm{p}-$, phosphorylated; GSK3 $\beta$, glycogen synthase kinase 3 $\beta$; HSF1, heat shock factor 1; Bax, B cell-2-associated X protein; KD, ILK silencing; HT, hyperthermia; NC, negative control; Con, control.

be assessed through the activation of HSF1, that is, the expression level of phosphorylated HSF1. In a study by He et al (17), HeLa cells were heated at $45^{\circ} \mathrm{C}$ for $30 \mathrm{~min}$, and the cells were then allowed to recover at $37^{\circ} \mathrm{C}$ for $0,2,4,6,8,10$ and $24 \mathrm{~h}$, and it was revealed that the DNA binding activity of HSF1 was highest following $8 \mathrm{~h}$. In another study by Bijur and Jope (25), neuroblastoma SH-SY5Y cells were heated at $45^{\circ} \mathrm{C}$ for $30 \mathrm{~min}$, allowed to recover at $37^{\circ} \mathrm{C}$ for $0,2,4,6,8,10$ and $24 \mathrm{~h}$, and the DNA binding activity of HSF1 was found to be highest after $4 \mathrm{~h}$. In the present study, Tca 8113 cells were heated at $45^{\circ} \mathrm{C}$ for $30 \mathrm{~min}$, and the cells were allowed to recover at $37^{\circ} \mathrm{C}$ for $0,2,4$, $6,8,10$ and $24 \mathrm{~h}$. The mRNA of HSF1 was highest after $6 \mathrm{~h}$ and the protein of HSF1 was highest after $8 \mathrm{~h}$, which is consistent with the experimental results of He et al (17). The rewarming time was different between the highest levels of HSF1 mRNA and the highest levels of HSF1 protein, which may be the reason that RNA was expressed substantially earlier than the protein. The heat sensitivity was worst and the thermal tolerance was highest after $8 \mathrm{~h}$, so subsequent experiments were performed at this time point. After silencing ILK, if the sensitivity of the thermotherapy increased at the given time point, the sensitivity of the thermotherapy should increase more significantly in other time points (because the other time points represented thermal tolerance conditions).

Changes of Tca8113 cell proliferation, migration and cell cycle were detected. It was revealed that hyperthermia combined with ILK gene silencing could significantly inhibit cell proliferation and migration and Tca8113 cells were arrested in the $\mathrm{S}$ phase. Tumor cells could not undergo mitosis, and apoptosis eventually occurred. This is in contrast from 
A
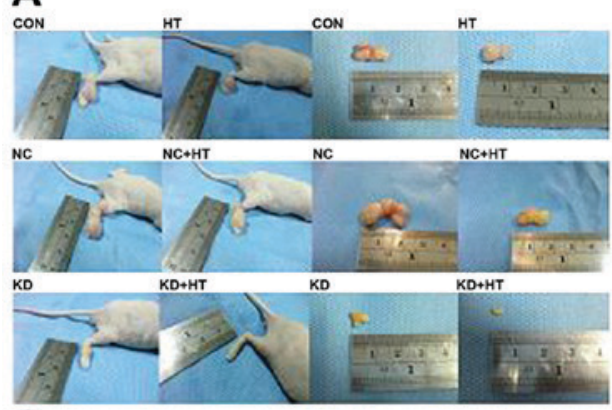

C

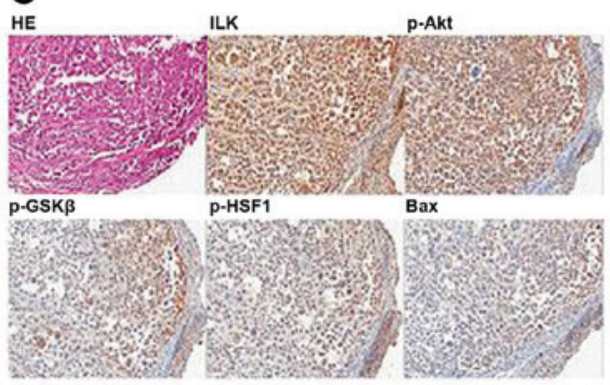

E

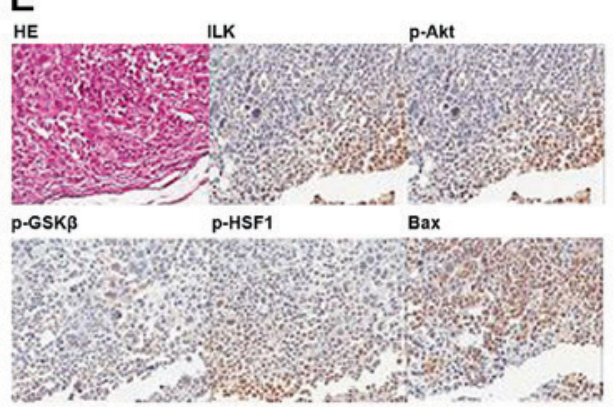

G
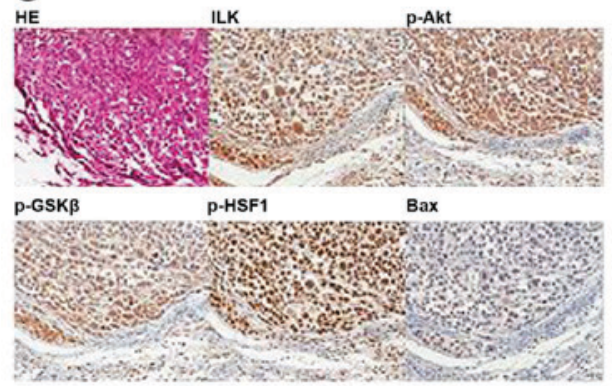

I

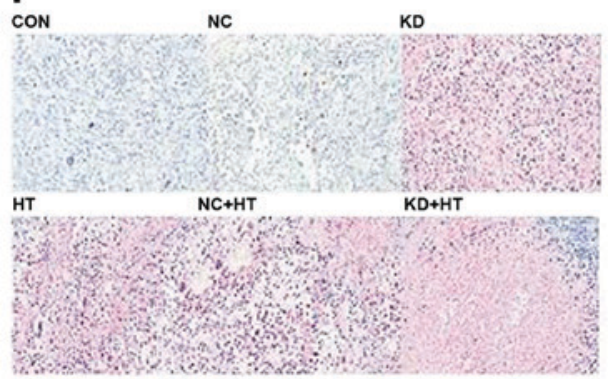

B

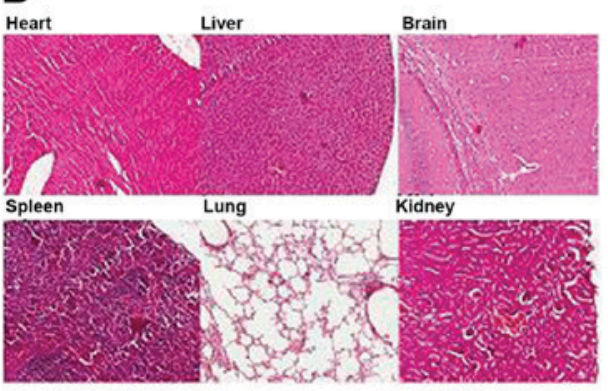

D

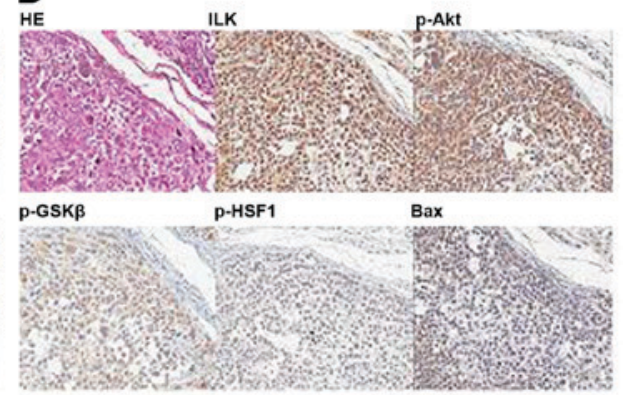

FE

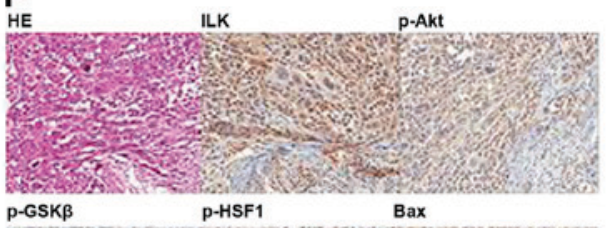

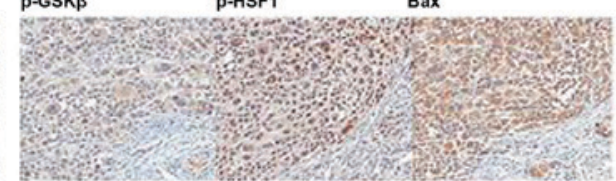

H
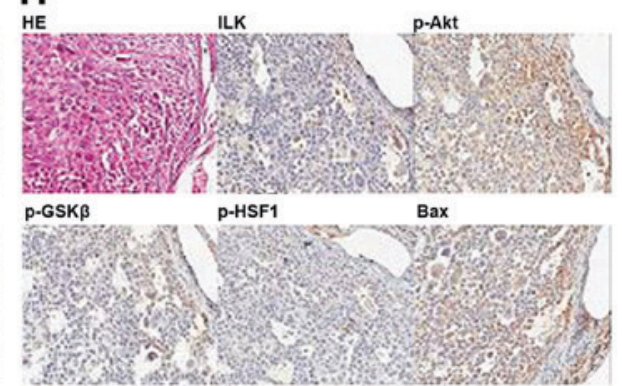

J

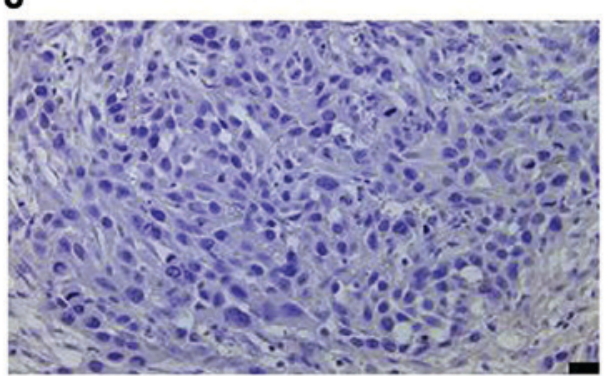

Figure 5. In vivo experiments of ILK silencing combined with hyperthermia (x400). (A) A total of 7 days after inoculation, the xenograft tumor formed. (B) There was no significant organic damage in heart, liver, brain, spleen, lung and kidney of nude mice following ILK silencing combined with hyperthermiaby H\&E staining (x100). (C) Results of H\&E staining and immunohistochemical analysis in the control group. Polygonal cells were in dense flocks, nuclei were large and deeply stained, the expression of ILK, p-Akt, p-GSK3 $\beta$ and p-HSF1 was high, and the expression of Bax was low. (D) The figures of the NC group were same as the control group. (E) Results of H\&E staining and IHC analysis in the KD group. (F) Results of H\&E staining and IHC analysis in the HT group. (G) Results of the NC + HT group were same as the HT group. (H) Results of the KD + HT group were similar to the HT group. (I) TUNEL analysis was used to detect cell apoptosis. Cell apoptosis was significantly increased in the KD group and KD + HT group. Fewer apoptotic cells were found in the HT group and the NC + HT group, and the smallest number of apoptotic cells were found in the control and NC groups. (J) IgG negative control. ILK, integrin-linked kinase; HT, hyperthermia; p-, phosphorylated; GSK3 $\beta$, glycogen synthase kinase 3 $\beta$; HSF1, heat shock factor 1; Bax, B cell-2-associated X protein; H\&E, hematoxylin and eosin; NC, negative control; Con, control; HT, hyperthermia; KD, ILK silencing. 
previous studies $(26,27)$, which reported that inhibition of ILK leads to tumor cells stagnating in the G1 phase.

The phosphorylation sites of Akt Ser473 can be completely suppressed when ILK is inhibited in certain tumor cells $(28,29)$. The present results were in agreement with this observation, but in OSCC cells, it was demonstrated that silencing ILK can significantly reduce the expression of p-HSF1. Previous studies have shown (30-32) that inhibition of the PI3K/Akt pathway can significantly improve the sensitivity of hyperthermia. It was also revealed that the expression of $\mathrm{p}-\mathrm{Akt}, \mathrm{p}-\mathrm{GSK} 3 \beta$ and $\mathrm{p}-\mathrm{HSF} 1$ were significantly reduced following ILK silencing. Therefore, ILK silencing significantly improved the sensitivity of hyperthermia. In addition, the apoptosis-associated protein Bax was found to be significantly increased in the KD + HT group, but was not significantly increased in the KD group and other groups, which indicated that ILK silencing combined with hyperthermia significantly increased apoptosis of Tca8113 cells. In contrast, it was also observed that p-Akt and p-GSK3 $\beta$ expression in the KD + HT group was reduced compared with those of the KD group, indicating that hyperthermia increased the ILK silencing effect as feedback, producing an increased inhibitive effect on the PI3K/Akt signaling pathway.

Finally, in vivo experiments revealed that the transplanted tumor volume and weight in the $\mathrm{KD}+\mathrm{HT}$ group were significantly reduced compared with other groups, and organ damage was not detected, which indicated the efficacy of the treatment. Similar results were obtained with in vitro experiments by the PI3K/Akt pathway and hyperthermia-associated protein immunohistochemistry and TUNEL analysis. In in vivo experiments, ILK silencing led to the sensitivity of hyperthermia increase in nude mice and hyperthermia could feedback to enhance the effect of ILK silencing; the combination therapy had a synergistic antitumor effect.

To conclude, the present study investigated the potential to withstand cancer-associated activities of ILK silencing combined with hyperthermia against OSCC in vitro and in vivo. The results demonstrated that ILK silencing led to Tca8113 cells and their transplanted tumors exhibiting increased hyperthermia sensitivity; and hyperthermia could feedback to enhance the effect of ILK silencing, consequently inhibiting the PI3K/Aktsignaling pathway. Therefore, the combination therapy had a synergistic antitumor effect.

\section{Acknowledgements}

The present study was supported by the project in Sichuan Province Scientific and Technological Support (grant no. 2011SZ0156), Hefei Science and Technology Research Program (grant no. 2015HK163) and Hefei's Independent Innovation Policy 'Borrow and Replace' Project (grant no. 2017).

\section{References}

1. Perri F, Muto P, Aversa C, Daponte A, Della Vittoria G, Pepe $\mathrm{S}$ and Caponigro $\mathrm{F}$ : Integrated therapeutic approaches in head and neck cancer: The importance of multidisciplinary team management. Anticancer Agents Med Chem 13: 834-843, 2013.

2. Antoniv TT and Ivashkiv LB: Interleukin-10-induced gene expression and suppressive function are selectively modulated by the PI3K-Akt-GSK3 pathway. Immunology 132: 567-577, 2011.
3. Aksamitiene E, Kiyatkin A and Kholodenko BN: Cross-talk between mitogenic Ras/MAPK and survival PI3K/Akt pathways: A fine balance. Biochem Soc Trans 40: 139-146, 2012.

4. Troussard AA, Mawji NM, Ong C, Mui A, St -Arnaud R and Dedhar S: Conditional knock-out of integrin-linked kinase demonstrates an essential role in protein kinase B/Akt activation. J Biol Chem 278: 22374-22378, 2003.

5. Marotta A, Parhar K, Owen D, Dedhar S and Salh B: Characterisation of integrin-linked kinase signalling in sporadic human colon cancer. Br J Cancer 88: 1755-1762, 2003.

6. Tasian SK, Teachey DT and Rheingold SR: Targeting the $\mathrm{PI} 3 \mathrm{~K} / \mathrm{mTOR}$ pathway in pediatric hematologic malignancies. Front Oncol 4: 108, 2014.

7. Zheng K, Wang G, Li C, Shan X and Liu H: Knockdown of ILK inhibits glioma development via upregulation of E-cadherin and downregulation of cyclin D1. Oncol Rep 34: 272-278, 2015.

8. Zhao X, Xu Z, Wang Z, Wu Z, Gong Y, Zhou L and Xiang Y: RNA silencing of integrin-linked kinase increases the sensitivity of the A549 lung cancer cell line to cisplatin and promotes its apoptosis. Mol Med Rep 12: 960-966, 2015.

9. Dicheva BM and Koning GA: Targeted thermosensitive liposomes: An attractive novel approach for increased drug delivery to solid tumors. Expert Opin Drug Deliv 11: 83-100, 2014.

10. Yamamoto D, Inui T, Tsubota Y, Sueoka N, Yamamoto C, Kuwana K and Yamamoto M: The utility of hyperthermia for local recurrence of breast cancer. World J Surg Oncol 10: 201, 2012.

11. Liang XH, He YW, Tang YL, Wu JL, Gao XP, Xiao GZ and Mao ZY: Thermochemotherapy of lower lip squamous cell carcinoma without metastases: An experience of 31 cases. J Craniomaxillofac Surg 38: 260-265, 2010.

12. Tao Y, Guo Y, Liu W, Zhang J, Li X, Shen L, Ru Y, Xue Y, Zheng J, Liu X, et al: AKT inhibitor suppresses hyperthermia-induced Ndrg2 phosphorylation in gastric cancer cells. Braz J Med Biol Res 46: 394-404, 2013.

13. Schaeffer DF, Assi K, Chan K, Buczkowski AK, Chung SW, Scudamore CH, Weiss A, Salh B and Owen DA: Tumor expression of integrin-linked kinase (ILK) correlates with the expression of the E-cadherin repressor snail: An immunohistochemical study in ductal pancreatic adenocarcinoma. Virchows Arch 456: 261-268, 2010.

14. Gao Z, Liu F, Yin P, Wan C, He S, Liu X, Zhao H, Liu T, Xu J and Guo $S$ : Inhibition of heat-induced apoptosis in rat small intestine and IEC-6 cells through the AKT signaling pathway. BMC Vet Res 9: 241, 2013.

15. Zhao D, Tang XF, Yang K, Liu JY and Ma XR: Over-expression of integrin-linked kinase correlates with aberrant expression of Snail, E-cadherin and N-cadherin in oral squamous cell carcinoma: implications in tumor progression and metastasis. Clin Exp Metastasis 29: 957-969, 2012.

16. Nakagawa T, Ohnishi K, Kosaki Y, Saito Y, Horlad H, Fujiwara Y, Takeya M and Komohara Y: Optimum immunohistochemical procedures for analysis of macrophages in human and mouse formalin fixed paraffin-embedded tissue samples. J Clin Exp Hematop 57: 31-36, 2017.

17. He B, Meng YH and Mivechi NF: Glycogen synthase kinase 3beta and extracellular signal-regulated kinase inactivate heat shock transcription factor 1 by facilitating the disappearance of transcriptionally active granules after heat shock. Mol Cell Biol 18: 6624-6633, 1998

18. Livak KJ and Schmittgen TD: Analysis of relative gene expression data using real-time quantitative PCR and the 2(-Delta Delta C(T)) method. Methods 25: 402-408, 2001.

19. Chen X, Zhang J, Han C, Dai H, Kong X, Xu L, Xia Q, Zhang M and Zhang J: A sexual dimorphism influences bicyclol-induced hepatic heat shock factor 1 activation and hepatoprotection. Mol Pharmacol 88: 38-47, 2015.

20. Rahman MA, Amin AR, Wang D, Koenig L, Nannapaneni S, Chen Z, Wang Z, Sica G, Deng X, Chen ZG and Shin DM: RRM2 regulates $\mathrm{Bcl}-2$ in head and neck and lung cancers: A potential target for cancer therapy. Clin Cancer Res 19: 3416-3428, 2013.

21. de la Torre NG, Buley I, Wass JA and Turner HE: Angiogensis and lymphangiogenesis in thyroid proliferative lesions: Relationship to type and tumour behaviour. Endocr Relat Cancer 13: 931-944, 2006.

22. Marchesin V, Castro-Castro A, Lodillinsky C, Castagnino A, Cyrta J, Bonsang-Kitzis H, Fuhrmann L, Irondelle M, Infante E, Montagnac G, et al: ARF6-JIP3/4 regulate endosomal tubules for MT1-MMP exocytosis in cancer invasion. J Cell Biol 211: 339-358, 2015. 
23. Qian DC, Byun J,Han Y, Greene CS, Field JK, Hung RJ, Brhane Y, Mclaughlin JR, Fehringer G, Landi MT, et al: Identification of shared and unique susceptibility pathways among cancers of the lung, breast, and prostate from genome-wide association studies and tissue-specific protein interactions. Hum Mol Genet 24: 7406-7420, 2015

24. Zeise E and Rensing L: Hyperthermia pre-treatment protects rats IPC-81 leukaemia cells against heat- and hydrogen peroxideinduced apoptosis. Int J Hyperthermia 18: 344-360, 2002.

25. Bijur GN and Jope RS: Opposing actions of phosphatidylinositol 3-kinase and glycogen synthase kinase-3beta in the regulation of HSF-1 activity. J Neurochem 75: 2401-2408, 2000.

26. Zhu XY, Liu N, Liu W, Song SW and Guo KJ: Silencing of the integrin-linked kinase gene suppresses the proliferation, migration and invasion of pancreatic cancer cells (Panc-1). Genet Mol Biol 35: 538-544, 2012.

27. Li Q, Li C, Zhang YY, Chen W, Lv JL, Sun J and You QS: Silencing of integrin-linked kinase suppresses in vivo tumorigenesis of human ovarian carcinoma cells. Mol Med Rep 7: 1050-1054, 2013.
28. Persad S, Attwell S, Gray V, Delcommenne M, Troussard A, Sanghera J and Dedhar S: Inhibition of integrin-linked kinase (ILK) suppresses activation of protein kinase B/Akt and induces cell cycle arrest and apoptosis of PTEN-mutant prostate cancer cells. Proc Natl Acad Sci USA 97: 3207-3212, 2000.

29. Makino K, Day CP, Wang SC, Li YM and Hung MC: Upregulation of IKKalpha/IKKbeta by integrin-linked kinase is required for HER 2/neu-induced NF-kappaB antiapoptotic pathway. Oncogene 23: 3883-3887, 2004.

30. Jevtov I, Zacharogianni M, van Oorschot MM, van Zadelhoff $G$, Aguilera-Gomez A, Vuillez I, Braakman I, Hafen E, Stocker H and Rabouille C: TORC2 mediates the heat stress response in Drosophila by promoting the formation of stress granules. J Cell Sci 128: 2497-2508, 2015

31. Ohnishi K, Yasumoto J, Takahashi A and Ohnishi T: LY294002, an inhibitor of PI-3K, enhances heat sensitivity independently of p53 status in human lung cancer cells. Int J Oncol 29: 249-253, 2006.

32. Ma N, Szmitko P, Brade A, Chu I, Lo A, Woodgett J, Klamut H and Liu FF: Kinase-dead PKB gene therapy combined with hyperthermia for human breast cancer. Cancer Gene Ther 11: 52-60, 2004. 